\title{
Studies on the Laccase of Lentinus edodes: Specificity, Localization and Association with the Development of Fruiting Bodies
}

\author{
By GARY F. LEATHAM† AND MARK A. STAHMANN* \\ Department of Biochemistry, College of Agricultural and Life Sciences, University of \\ Wisconsin-Madison, Madison, Wisconsin 53706, U.S.A.
}

(Received 26 September 1980)

The phenol oxidases from mature fruiting bodies of Lentinus edodes (Berk.) Sing., a
commercially cultivated mushroom, were studied. The major phenol oxidase was a laccase
with a pH optimum near 4.0 and an apparent molecular weight of 100000 . Catechol oxidase
and tyrosinase were also present. The laccase investigated was primarily extracellular; the
highest activity was in the pigmented rind of the pileus and in the stipe. Increased laccase
activity was associated with rapid growth of non-pigmented aerial mycelium and formation of
pigmented primordia and fruiting bodies. Possible functions of the laccase and its regulation
during the development of fruiting bodies are discussed.

\section{INTRODUCTION}

Phenol oxidases are of widespread occurrence in animals, green plants and fungi (Mason, 1955). There are three major types of phenol oxidases distinguishable by substrate specificity and the use of inhibitors; however, all appear to be oxygen-dependent, copper-containing glycoproteins. Tyrosinase has both monophenol oxidase (EC 1.14.18.1) and catechol oxidase (EC 1.10.3.1) activities, and is inhibited by carbon monoxide (Mason, 1957); it catalyses the $o$-hydroxylation of monophenols and then oxidizes the $o$-diphenols to their reactive $o$-quinones. Catechol oxidase often exhibits similar specificity to tyrosinase but cannot hydroxylate monophenols. Laccase (EC 1.10.3.2) catalyses the oxidation of $o$ - and $p$-diphenols and of diaminoaromatic compounds (e.g. $p$-hydroquinone, $p$-phenylenediamine and benzidine), and is not inhibited by carbon monoxide.

Tyrosinase is responsible for the pigmentation and hardening of the cuticle of insects. During the formation of insect cuticle, extracellular phenolic substrates are oxidized to form $o$-quinones, which react with proteins and other quinones forming an insoluble cross-linked protein complex (Mason, 1955; Hackman, 1959). In the formation of higher plant secondary cell walls a somewhat analogous situation has been reported for the extracellular deposition of lignin (Higuchi, 1959; Northcote, 1972).

Laccase was first characterized from the latex of the Japanese lacquer tree (Rhus verniciflua) as the thermolabile substance responsible for catalysing the oxidative polymerization of lipophilic alkene-catechol compounds (e.g. urushiol) to form a hard black lacquer (summarized by Schubert, 1965). Laccase is of widespread distribution in fungi. Increased phenol oxidase activity and pigmentation have often been reported to be associated with rapid cell growth and with the formation of primordia and their subsequent growth to fruiting bodies in both basidiomycetes (Leonard \& Phillips, 1973; Wood \& Goodenough, 1977; Wood, 1980) and ascomycetes (Esser, 1968; Wong \& Willetts, 1974), and also in the development of sporangiophores of the slime mould Physarum polycephalum (Daniel, 1963).

† Present address: USDA Forest Service, Forest Products Laboratory, P.O. Box 5130, Madison, Wisconsin 53705, U.S.A. 
Fruiting bodies of a large number of higher fungi are reported to contain laccase. The bulk of the laccase was reported to be localized in tissues undergoing active growth, even when the tissues were not noticeably pigmented (Harkin et al., 1974). Phenol oxidase catalysed the pigmentation of the thick-walled resistant spores of the phycomycete Blastocladiella emersonii and was reported to be coupled to metabolism (Cantino \& Lovett, 1964). An involvement of phenol oxidase in respiratory metabolism in Aspergillus nidulans was predicted by Bull \& Carter (1973). Although much work has been done on the phenol oxidases of higher fungi no general hypothesis has been accepted as to how the phenol oxidase activity or the formation of pigment may be involved in fruiting.

Initial characterization of the phenol oxidases in fruiting bodies of Lentinus edodes using partially purified enzyme preparations, with $o$-diphenols, $p$-cresol and $p$-hydroquinone as substrates, and carbon monoxide as an inhibitor, suggested that phenol oxidases other than laccase were present (Fujimoto et al., 1972). In the work reported here we have verified this finding. However, by using whole fresh mushroom homogenates as an enzyme source, $p$-phenylenediamine and benzidine analogues as substrates, and a range of inhibitors, we have also detected laccase. We report the substrate and inhibitor specificity, $\mathrm{pH}$ optimum, molecular weight and localization of the laccase, and its association with colony growth and fruiting. A hypothesis concerning the regulation and possible function(s) of the laccase is presented.

\section{METHODS}

Organism. Lentinus edodes strain RA-3-2E was selected for its ability to fruit at $21^{\circ} \mathrm{C}$ in flask culture from the Japanese commercial strain 904 Meiji which has been the stock culture of this laboratory since 1968 . Stock cultures were maintained at $21^{\circ} \mathrm{C}$ and $4^{\circ} \mathrm{C}$ on Sabouraud maltose agar (Difco).

Inoculum production. Agar plugs $(2 \times 2 \times 2 \mathrm{~mm})$ were transferred from a stock culture into cotton-stoppered $250 \mathrm{ml}$ Erlenmeyer flasks which each contained $1 \mathrm{~g}$ oat flour (Dietetic Cellu Foods, Chicago Dietetic Supply, LaGrange, Ill., U.S.A.) and $20 \mathrm{ml}$ of a defined medium. This medium contained (per litre): $25 \mathrm{~g}$ D-glucose, $2 \mathrm{~g}$ L-glutamic acid, $2.5 \mathrm{~g} \mathrm{KH}_{2} \mathrm{PO}_{4}, 2.5 \mathrm{~g} \mathrm{MgSO}_{4}$ (anhydrous); a trace element solution supplying (final concentrations, per litre) $18 \mathrm{mg} \mathrm{Ca}^{2+}, 0.24 \mathrm{mg} \mathrm{Na}^{+}, 0.23 \mathrm{mg} \mathrm{Zn}^{2+}, 0.14 \mathrm{mg} \mathrm{Fe}^{3+}, 0.14 \mathrm{mg} \mathrm{Mn}^{2+}, 0.06 \mathrm{mg} \mathrm{Cu}{ }^{2+}$, $0.015 \mathrm{mg} \mathrm{Co}^{2+}, 0.010 \mathrm{mg} \mathrm{Mo}^{6+}$ and $0.010 \mathrm{mg} \mathrm{B}^{3+}$; and a vitamin solution supplying (final concentrations, per litre) $2 \mathrm{mg}$ choline hydrochloride, $2 \mathrm{mg}$ i-inositol, $235 \mu \mathrm{g}$ nicotinamide, $135 \mu \mathrm{g}$ thiamin, $100 \mu \mathrm{g}$ pyridoxine, $40 \mu \mathrm{g}$ calcium pantothenate folate, $30 \mu \mathrm{g}$ biotin and $30 \mu \mathrm{g}$ riboflavin. The medium was autoclaved for $20 \mathrm{~min}$ at $121^{\circ} \mathrm{C}$; its final $\mathrm{pH}$ was $3 \cdot 5$.

After 20-40 d growth without shaking, the contents of four culture flasks were homogenized in a Waring blender for $20 \mathrm{~s}$ in $100 \mathrm{ml}$ distilled water and transferred to duplicate 21 fermenters. The medium in these fermenters consisted of $1 \%(\mathrm{w} / \mathrm{v})$ oat flour in $1.5 \mathrm{l}$ of the defined medium, autoclaved in the fermenter for $40 \mathrm{~min}$ at $121^{\circ} \mathrm{C}$; the final $\mathrm{pH}$ was approximately $3 \cdot 6$. The cultures were grown in the 21 fermenter for $4-6 \mathrm{~d}$ at $25 \pm$ $1{ }^{\circ} \mathrm{C}$ with aeration with filter-sterilized air at $0.351 \mathrm{~min}^{-1}$ and stirring at $150 \mathrm{rev} \cdot \mathrm{min}^{-1}$, causing the formation of small mycelial pellets. The resulting liquid culture was used either directly to inoculate flasks or to inoculate a 201 fermenter (New Brunswick; model MF-128) to produce larger quantities of inoculum. The medium for the 201 fermenter was the same as for the 21 fermenters, but autoclaved for $60 \mathrm{~min}$ at $121^{\circ} \mathrm{C}$. The 31 of fermenter-grown inoculum was transferred to the 201 fermenter and the culture was grown for $4 \mathrm{~d}$ at $25 \pm 1{ }^{\circ} \mathrm{C}$ with aeration with filter-sterilized air at $5.51 \mathrm{~min}^{-1}$ and stirring at $175 \mathrm{rev} \cdot \mathrm{min}^{-1}$.

Flask culture. Two media were used for fruiting body production of $L$. edodes in cotton-stoppered $250 \mathrm{ml}$ Erlenmeyer flasks. These contained (per flask): $1 \mathrm{~g}$ rolled oats in $20 \mathrm{ml}$ distilled water, or $1 \mathrm{~g}$ xylose/cellulose (Sigmacell)/vitamin-free casein $(2 \cdot 25: 2 \cdot 25: 1 \cdot 00$, by wt); $20 \mathrm{ml}$ defined medium (as above) minus glucose; $50 \mu \mathrm{l}$ oak (Quercus sp.) bark extract. The oak bark extract was made from one part oak bark (from a debarking machine at a pallet manufacturing factory) added to 10 parts boiling distiiled water, followed by steeping for $2 \mathrm{~h}$. The media were autoclaved for $20 \mathrm{~min}$ at $121{ }^{\circ} \mathrm{C}$ and inoculated with $5 \mathrm{ml}$ of fermenter-grown inoculum. The cultures were grown at $21 \pm 2{ }^{\circ} \mathrm{C}$ with illumination at $170-345 \mathrm{~lx}$ by $40 \mathrm{~W}$ Gro-Lux fluorescent bulbs (Sylvania, Danvers, Mass., U.S.A.) on a $9 \mathrm{~h}$ light $/ 15 \mathrm{~h}$ dark cycle. Fruiting occurred 22 to $35 \mathrm{~d}$ after inoculation.

Preparation of tissues for enzyme assays. Homogenates of whole flask contents were made by diluting the contents of a flask culture with distilled water to a final volume of $40 \mathrm{ml}$ and homogenizing in a Waring blender for $1 \mathrm{~min}$. Tissue homogenates were made from the tissue taken from flask cultures by forceps or from fresh mushrooms; homogenization was done in a Waring blender in $40 \mathrm{ml}$ distilled water for $1 \mathrm{~min}$ for flask-grown 
tissue, and in a 10-fold ( $\mathrm{w} / \mathrm{v}$ ) excess of distilled water for $2 \mathrm{~min}$ for fresh mushrooms. The culture filtrate from flask cultures was prepared by decanting the medium and homogenizing it for $1 \mathrm{~min}$ in a Waring blender. Unless otherwise stated, all homogenates were centrifuged at $500 \mathrm{~g}$ for $10 \mathrm{~min}$ and the supernatant was assayed.

Enzyme assays. The assay mixture was made by adding to a cuvette $1 \mathrm{ml} 1 \mathrm{~mm}$ substrate, $1 \mathrm{ml} 50 \mathrm{~mm}$ buffer, $0.2 \mathrm{ml}$ distilled water or other additions, and $0.2 \mathrm{ml}$ of the sample for assay of phenol oxidase (all additions at $25^{\circ} \mathrm{C}$ ). The oxidation of substrates was measured at a predetermined wavelength with a $1 \mathrm{~cm}$ optical path length in a Gilson DU single-beam spectrophotometer equipped with a water-jacketed sample chamber maintained at 25 $\pm 0.2{ }^{\circ} \mathrm{C}$. The steady-state oxidation rate of the phenolic substrate was determined from recorder tracings. Unless otherwise stated, 3,3'-dimethylbenzidine (3,3'-dimethyl-4,4'-diaminodiphenyl) was the substrate for laccase in $50 \mathrm{~mm}$-sodium acetate $/ \mathrm{HCl}$ buffer, $\mathrm{pH} 4.5$, monitored at $600 \mathrm{~nm}$, and 3-(3,4-dihydroxyphenyl)-L-alanine (L-DOPA) was the phenolic substrate for catechol oxidase in the same buffer, monitored at $450 \mathrm{~nm}$ (inhibitor studies suggested that L-DOPA was not oxidized by the laccase). Enzyme activities were expressed on a fresh weight or per flask basis. The moisture content of the fruiting body tissues was $85-92 \%$. Unless otherwise stated, duplicates of each sample were measured, the mean value being reported, and the standard deviation was less than or equal to $10 \%$.

Gel filtration chromatography. A crude laccase preparation was made by homogenizing $57 \mathrm{~g}$ of whole fresh mushrooms in $200 \mathrm{ml} 100 \mathrm{~mm}$-sodium acetate/ $\mathrm{HCl}$ buffer, $\mathrm{pH} 4 \cdot 5$, in a Waring blender for $2 \mathrm{~min}$ at $21^{\circ} \mathrm{C}$. The homogenate was centrifuged at $1000 \mathrm{~g}$ for $5 \mathrm{~min}$, and $80 \mathrm{ml}$ of the supernatant was concentrated to $8 \mathrm{ml}$ in dialysis tubing packed in sucrose at $4{ }^{\circ} \mathrm{C}$. The apparent molecular weight of the laccase was determined by gel filtration of $6.5 \mathrm{ml}$ of the concentrated homogenate applied to a Bio-Rad P-200 gel in a $3 \times 90 \mathrm{~cm}$ column equilibrated with the same buffer at $21 \pm 2{ }^{\circ} \mathrm{C}$, using ascending flow with a $15 \mathrm{~cm}$ constant pressure head, and collecting $7 \mathrm{ml}$ fractions. The proteins used to calibrate the column for apparent molecular weight determination were glucose oxidase (mol. wt 150000), $\alpha$-amylase (97600), bovine serum albumin (69000), $\beta$-lactoglobulin (35000) and lysozyme (14400). Blue dextran was used as the void volume marker.

Polyacrylamide gel electrophoresis. Polyacrylamide gel electrophoresis was carried out at $16^{\circ} \mathrm{C}$ with $3 \mathrm{~mm}$ thick $5 \%(\mathrm{w} / \mathrm{v})$ slab gels, by the method of Davis (1964) but with the omission of both the spacer and small-pore gel layers. One vol. of a solution containing $30 \%(\mathrm{w} / \mathrm{v})$ sucrose and $0.06 \%(\mathrm{w} / \mathrm{v})$ bromophenol blue was added to the samples. Electrophoresis was continued at $5 \mathrm{~mA}$ per cm gel width until the tracking dye had migrated $15 \mathrm{~cm}$. Staining for laccase was done with $1 \mathrm{~mm}$-benzidine in $100 \mathrm{~mm}$-sodium acetate buffer, $\mathrm{pH} 4.5$, for $3 \mathrm{~h}$ at $21^{\circ} \mathrm{C}$, followed by overnight destaining in the same buffer. Bands of laccase appeared as stable dark blue-black bands.

\section{RES ULTS}

\section{Types of phenol oxidase present}

The rates of oxidation $\left(\Delta A \mathrm{~min}^{-1}\right)$ of various substrates at $0.42 \mathrm{~mm}$ catalysed by the phenol oxidases from whole fresh mushroom homogenates were determined at $\mathrm{pH} 4.5$ in 21 mM-sodium acetate buffer and at pH 6.5 in 21 mM-sodium phosphate buffer at $25{ }^{\circ} \mathrm{C}$ (Table 1). The wavelength of maximal absorbance $\left(\lambda_{\max }\right)$ for each oxidized substrate was determined from its absorption spectrum after sodium periodate oxidation. For several of the substrates, a molar absorption coefficient $\left(\varepsilon^{0}\right)$ at $\lambda_{\max }$ was determined by oxidizing the substrate with a known concentration of sodium periodate under standard enzyme assay conditions. When phenol oxidase was determined with tissue homogenates, the presence of reducing compounds (possibly endogenous phenolics) often caused an initial lag period in the oxidation of the substrate. This lag period did not occur after overnight storage of the homogenates at $4{ }^{\circ} \mathrm{C}$, presumably as a result of the oxidation of the interfering reducing compounds. The steady-state rate of oxidation of a substrate, however, was identical for a given homogenate before or after storage and it was constant during the assay. Therefore, phenol oxidase was estimated in fresh homogenates using the steady-state rate of substrate oxidation. In whole fresh mushroom homogenates, two distinct types of phenol oxidases were found. The major phenol oxidase was laccase, with an activity of $34.2 \mu \mathrm{mol}$ substrate oxidized $\min ^{-1}$ (g fresh wt tissue $)^{-1}$ based on the oxidation of $3,3^{\prime}$-dimethylbenzidine at $\mathrm{pH} \mathrm{4.5}$. Catechol oxidase was also detected; its activity based on the oxidation of L-DOPA was about one-tenth that of the laccase. Tyrosinase activity was also present. The laccase had a preference for $p$-substituted diamines and a $\mathrm{pH}$ optimum below $6 \cdot 5$. The catechol oxidase and tyrosinase had a broad $\mathrm{pH}$ specificity, with similar activity at $\mathrm{pH} 4.5$ and 6.5 . Substrate specificity for the oxidation of $o$-diphenols was greater at $\mathrm{pH} 6.5$ than at $\mathrm{pH} 4 \cdot 5$. However, it is not known 
Table 1. Rates of oxidation of substrates by a whole fresh mushroom homogenate

The oxidation rates are expressed as the mean steady-state rate of oxidation of substrates $(0.42 \mathrm{~mm})$ for duplicate assays. Buffers were $21 \mathrm{~mm}$-sodium acetate, $\mathrm{pH} 4.5$, and $21 \mathrm{~mm}$-sodium phosphate, $\mathrm{pH} 6 \cdot 5$. The assay wavelength was that of the maximal absorbance $\left(\lambda_{\max }\right)$ for the oxidized substrate. The molar absorption coefficients $\left(\varepsilon^{0}\right)$ for oxidized substrates were determined by sodium periodate oxidation.

\begin{tabular}{|c|c|c|c|c|c|}
\hline \multirow[b]{2}{*}{ Substrate } & \multicolumn{2}{|c|}{ Oxidation rate $\left(\Delta A \mathrm{~min}^{-1}\right)$} & \multirow{2}{*}{$\begin{array}{c}\text { Assay } \\
\text { wavelength } \\
(\mathrm{nm})\end{array}$} & \multicolumn{2}{|c|}{$10^{-3} \times \varepsilon^{0}(\underbrace{1} \mathrm{~mol}^{-1} \mathrm{~cm}^{-1})$} \\
\hline & $\mathrm{pH} 4.5$ & $\mathrm{pH} 6.5$ & & $\mathrm{pH} 4 \cdot 5$ & $\mathrm{pH} 6 \cdot 5$ \\
\hline$p$-Anisidine & 0.026 & 0.000 & 460 & - & - \\
\hline$p$-Anisidine $+1 \mathrm{mM}-\mathrm{H}_{2} \mathrm{O}_{2}$ & 0.026 & 0.000 & 460 & - & - \\
\hline Tyrosine & 0.027 & 0.020 & 460 & - & - \\
\hline L-DOPA & 0.075 & 0.070 & 460 & 3.85 & 3.96 \\
\hline Caffeic acid & 0.064 & 0.024 & 390 & - & - \\
\hline Chlorogenic acid & 0.054 & 0.000 & 390 & - & - \\
\hline$o$-Phenylenediamine & $0 \cdot 500$ & 0.000 & 440 & $7 \cdot 60$ & - \\
\hline$p$-Phenylenediamine & 0.706 & 0.000 & 460 & - & - \\
\hline Dimethylenediamine & 0.640 & 0.090 & 510 & - & - \\
\hline Benzidine & 0.943 & 0.000 & 600 & $8 \cdot 87$ & - \\
\hline Benzidine $+1 \mathrm{mM}-\mathrm{H}_{2} \mathrm{O}_{2}$ & 0.950 & 0.000 & 600 & 8.87 & - \\
\hline 3,3'-Dimethylbenzidine & $1 \cdot 640^{*}$ & 0.000 & 600 & $6 \cdot 34$ & - \\
\hline 3,3'-Dimethoxybenzidine & $2 \cdot 836$ & $2 \cdot 040$ & 375 & \multicolumn{2}{|c|}{ not stable } \\
\hline 1,3-Dihydroxynaphthalene & 0.036 & 0.000 & 440 & - & - \\
\hline
\end{tabular}

if more than one tyrosinase or catechol oxidase was present. There was no enhanced oxidation of phenolics in the presence of hydrogen peroxide; therefore, peroxidase was insignificant compared with phenol oxidase activity.

Inhibitors were used to substantiate the presence of two classes of phenol oxidases in whole fresh mushroom homogenates. The following inhibited the laccase-catalysed oxidation of $3,3^{\prime}$-dimethylbenzidine and 3,3'-dimethoxybenzidine but not the oxidation of L-DOPA: $20 \mu \mathrm{M}$-sodium azide, $1 \mathrm{mM}$-sodium cyanate, $1 \mathrm{mM}$ - $o$-phthalate, $12 \mu \mathrm{M}$ - $\alpha$-naphthol, 12 $\mu \mathrm{M}-\beta$-naphthol and $1 \mathrm{mM}$-3-indoleacetic acid (Table 2). Therefore L-DOPA was a useful substrate for study of the catechol oxidase. Catechol oxidase, but not laccase, was stimulated by $o$-phthalate and $\alpha$-naphthol and inhibited by $20 \mu \mathrm{M}$-sodium diethyldithiocarbamate.

\section{Properties of the laccase}

Whole fresh mushroom homogenates were used as the enzyme source to characterize the laccase(s). The kinetic parameters for the laccase-catalysed oxidation of 3,3'-dimethylbenzidine at $\mathrm{pH} 4.5$ and the mode of inhibition by $\alpha$ - and $\beta$-naphthol were investigated by means of Lineweaver-Burk plots. $\alpha$-Naphthol was a non-competitive inhibitor and $\beta$-naphthol was a competitive inhibitor. Azide and benzoate were also found to be non-competitive inhibitors and 3-indoleacetic acid a competitive inhibitor. In the absence of inhibitors, the kinetic parameters for the oxidation of $3,3^{\prime}$-dimethylbenzidine at $\mathrm{pH} 4.5$ were a $K_{\mathrm{m}}$ of 11.2

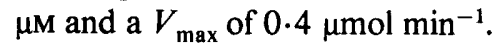

The $\mathrm{pH}$ optimum for the laccase with $3,3^{\prime}$-dimethylbenzidine as substrate was approximately $4 \cdot 0$, with little or no activity below $\mathrm{pH} 3 \cdot 0$ or above $\mathrm{pH} 5 \cdot 5$. The $\mathrm{pH}$ optimum with $p$-phenylenediamine and $N, N^{\prime}$-dimethyl-p-phenylenediamine was also 4.0 However, with $N, N, N^{\prime}, N^{\prime}$-tetramethyl-p-phenylenediamine the $\mathrm{pH}$ optimum was $5 \cdot 0$.

The effect of various cations on laccase activity was studied using $240 \mathrm{~mm}$ monovalent and $240 \mu \mathrm{M}$ divalent cations. $\mathrm{Na}^{+}, \mathrm{K}^{+}, \mathrm{Mg}^{2+}, \mathrm{Ca}^{2+}$ and $\mathrm{Mn}^{2+}$ had no effect. However, $\mathrm{Cu}^{2+}$ gave 
Table 2. Effect of inhibitors on phenol oxidase activity in a whole fresh mushroom homogenate

Values are expressed as the mean percentage inhibition of the steady-state rate of oxidation of substrates $\left(\Delta A \min ^{-1}\right)$ by inhibitors for duplicate assays.

\begin{tabular}{|c|c|c|c|c|c|}
\hline \multirow[b]{3}{*}{ Inhibitor } & \multirow[b]{3}{*}{$\begin{array}{l}\text { Inhibitor } \\
\text { concn }\end{array}$} & \multicolumn{4}{|c|}{ Percentage inhibition } \\
\hline & & \multicolumn{2}{|c|}{ Acetate buffer, $\mathrm{pH} 4.5$} & \multicolumn{2}{|c|}{ Phosphate buffer, $\mathrm{pH} 6.5$} \\
\hline & & $\begin{array}{l}\text { 3,3'-Dimethyl- } \\
\text { benzidine }\end{array}$ & L-DOPA & $\begin{array}{l}\text { 3,3'-Dimethoxy- } \\
\text { benzidine }\end{array}$ & L-DOPA \\
\hline None & & 0.0 & 0.0 & 0.0 & 0.0 \\
\hline Azide & $1.0 \mathrm{~mm}$ & $100 \cdot 0$ & - & - & $46 \cdot 0$ \\
\hline Azide & $20 \cdot 0 \mu \mathrm{M}$ & $68 \cdot 8$ & - & $76 \cdot 0$ & 0.0 \\
\hline Diethyldithiocarbamate & $1.0 \mathrm{~mm}$ & $100 \cdot 0$ & - & 87.0 & $95 \cdot 0$ \\
\hline Diethyldithiocarbamate & $0.1 \mathrm{~mm}$ & $35 \cdot 0$ & - & - & - \\
\hline Diethyldithiocarbamate & $20 \cdot 0 \mu \mathrm{M}$ & $4 \cdot 5$ & - & $0 \cdot 0$ & $61 \cdot 0$ \\
\hline Benzoate & $1.0 \mathrm{~mm}$ & $58 \cdot 0$ & - & - & $40 \cdot 0$ \\
\hline Cyanate & $1.0 \mathrm{~mm}$ & $68 \cdot 0$ & - & - & 0.0 \\
\hline$o$-Phthalate & $1.0 \mathrm{~mm}$ & $80 \cdot 0$ & - & - & $-60 \cdot 0^{*}$ \\
\hline 3-Indoleacetic acid & $1.0 \mathrm{~mm}$ & $64 \cdot 0$ & 0.0 & $90 \cdot 0$ & $2 \cdot 0$ \\
\hline 3-Indoleacetic acid & $50 \cdot 0 \mu \mathrm{M}$ & $42 \cdot 8$ & - & - & - \\
\hline$\alpha$-Naphthol & $0.6 \mathrm{~mm}$ & $98 \cdot 0$ & - & - & - \\
\hline$\alpha$-Naphthol & $12.0 \mu \mathrm{M}$ & $83 \cdot 3$ & 0.0 & - & $-20 \cdot 0^{*}$ \\
\hline$\beta$-Naphthol & $0.6 \mathrm{~mm}$ & 94.8 & - & - & - \\
\hline$\beta$-Naphthol & $12.0 \mu \mathrm{M}$ & 76.8 & 0.0 & - & - \\
\hline
\end{tabular}

- , Not determined.

* A stimulation of the oxidation of L-DOPA occurred with $o$-phthalate and $\alpha$-naphthol.

a $36 \%$ stimulation of laccase. This was consistent with the laccase being a copper metalloenzyme and suggested that copper-deficient apoenzymes might be present in the homogenate.

A whole fresh mushroom homogenate was subjected to gel filtration chromatography on a Bio-Rad P-200 column. One peak of laccase activity was obtained which was separate from the major protein $\left(A_{280}\right)$ peak. A single peak of a brown polyphenol or pigment, absorbing strongly in the ultraviolet and blue wavelengths, was also found. The apparent molecular weights of the single major protein peak, the laccase peak, and the brown polyphenol or pigment peak were 120000,100000 and 35000, respectively. Polyacrylamide slab gel electrophoresis of the laccase preparations, followed by staining with benzidine at $\mathrm{pH} 4.5$, showed more than one isoenzyme band. It was not ascertained whether the isoenzyme bands were artefacts caused by partial protease digestion or differences in carbohydrate constituents, or whether they occur naturally.

\section{Localization of the laccase}

Localization of laccase in relation to mushroom structure was studied by dissecting large whole fresh mushrooms and then assaying for laccase. Mushrooms were dissected into the lower and upper stipe (lightly pigmented), gills, rind (the deeply pigmented uppermost surface), and the outer rim of the pileus leaving behind the inner pileus tissue. The rim consisted of mostly rind with some pileus tissue and gills. Laccase activity was present in all the mushroom tissues examined. On a fresh tissue weight basis it was greatest in the rind and rim, followed by the stipe, pileus tissue and gills, in that order (Table 3 ). Thus the highest activity was associated with areas of pigmentation and with tissues responsible for structural support. It was found preferable to express tissue laccase activities on a fresh weight basis rather than a (Lowry) protein basis because reducing compounds (possibly phenolics) in the tissues gave falsely elevated estimates of protein by the Lowry technique. These reducing 
Table 3. Localization of laccase activity in relation to fruiting body structure

Tissue weights are expressed on a fresh weight basis. Laccase activities are expressed as the mean steady-state rate of oxidation of 3,3'-dimethylbenzidine in $21 \mathrm{~mm}$-sodium acetate buffer, $\mathrm{pH} 4 \cdot 5$, for duplicate assays. One unit of laccase catalyses the oxidation of $1 \mu \mathrm{mol}$ substrate $\mathrm{min}^{-1}$.

Tissue wt
Tissue source
body wt)

Lower stipe

Upper stipe

Gills

Pileus tissue

Rind (pigmented surface)

Rim (some rind, gills and pileus)

$10 \cdot 2$

13.8

22.9

$34 \cdot 7$

$14 \cdot 3$

$4 \cdot 1$

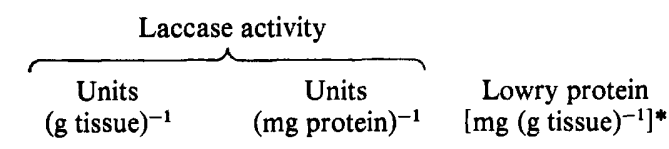

$57 \cdot 3$

$55 \cdot 2$

14.4

27.5

84.4

62.5
9.81

6.78

1.74

$4 \cdot 50$

11.11

5.75
$5 \cdot 84$

$8 \cdot 14$

$8 \cdot 28$

$6 \cdot 11$

$7 \cdot 60$

$10 \cdot 87$

* Interference by endogenous reducing compounds gave falsely elevated protein determinations by the Lowry method.

\section{Table 4. Differential centrifugation of laccase activity from a whole fresh mushroom homogenate}

Values are expressed as the mean steady-state rate of oxidation $\left[\mu \mathrm{mol} \mathrm{min}^{-1}(\mathrm{~g} \text { fresh wt tissue })^{-1}\right]$ of 3,3'-dimethylbenzidine in sodium acetate buffer, $\mathrm{pH} 4.5$, for each fraction relative to that for the crude homogenate without cell breakage, for duplicate assays. Cells were broken in a French press at $55 \mathrm{MPa}$.

\begin{tabular}{lcc}
\multicolumn{1}{c}{ Sample } & \multicolumn{2}{c}{ Relative laccase activity } \\
\cline { 2 - 3 } Cells intact & Cells broken \\
Crude homogenate & $1 \cdot 00$ & 1.20 \\
$500 \mathrm{~g}, 10$ min supernatant & 0.93 & 1.07 \\
$10800 \mathrm{~g}, 10$ min supernatant & $1 \cdot 17$ & 1.07 \\
$20200 \mathrm{~g}, 10$ min supernatant & $1 \cdot 14$ & 0.99 \\
$100000 \mathrm{~g}, 60$ min supernatant & $1 \cdot 12$ & 1.09 \\
$100000 \mathrm{~g}, 120$ min supernatant & $1 \cdot 17$ & 1.11 \\
$10800 \mathrm{~g}, 10$ min pellet & - & 0.10 \\
$20200 \mathrm{~g}, 10$ min pellet & - & 0.10 \\
$100000 \mathrm{~g}, 120$ min pellet & - & 0.10 \\
& - , Not determined. &
\end{tabular}

compounds were especially prevalent in the tissues still growing at the time of harvest, i.e. the rim, gills and upper stipe.

The cellular location of laccase was studied by differential centrifugation of whole fresh mushroom homogenates, half of each homogenate receiving no further treatment and half being treated in a French press at $55 \mathrm{MPa}$ prior to laccase assay. The results for a typical homogenate are shown in Table 4. Most of the laccase was solubilized into the supernatant fractions by the initial homogenization, even though with only this treatment about $80 \%$ of the individual cells were found to be unbroken on examination with a light microscope. Next, a whole fresh mushroom was cut into pieces of sides $2-4 \mathrm{~mm}$, which were rinsed quickly three times in distilled water, blotted, and then placed into $50 \mathrm{mM}$-sodium acetate buffer, $\mathrm{pH}$ 4.5, under the following osmotic conditions: hypotonic (no further addition), isotonic $(0.2 \mathrm{M}$-glucose) or hypertonic $(0.2 \mathrm{M}-\mathrm{KCl})$. After a $2 \mathrm{~h}$ soaking, $65-72 \%$ of the total remaining laccase had leached out under each of the treatments. It was concluded that the bulk of the laccase was extracellular and hence may have an extracellular function. 
The possible regulation of laccase and other extracellular enzymes by $\mathrm{pH}$

Since pigmentation differences by observation were more marked than the differences in laccase distribution, it was postulated that the site of phenolic substrate secretion might be a mechanism for the regulation of laccase function. However, other possibilities also exist such as the presence of endogenous activators or inhibitors. Using serial enzyme dilutions, no activators were detected in whole fresh mushroom homogenates. However, a $10-20 \%$ (0-50\% maximum) inhibition was detected which may have been due to the presence of inhibitors.

To measure the extracellular $\mathrm{pH}$ of a mature fruiting body, a whole fresh mushroom minus the rind was cut into pieces of sides $4-5 \mathrm{~mm}$ and soaked in distilled water $(1: 10, \mathrm{w} / \mathrm{v})$ for 20 min at $21^{\circ} \mathrm{C}$; the $\mathrm{pH}$ of the suspension was then measured with a $\mathrm{pH}$ meter. The $\mathrm{pH}$ of the mushroom minus the rind was $5.8 \pm 0.4$, and that of the rind was $5.0 \pm 0.25$. Based on the $\mathrm{pH}$ optimum for the oxidation of the experimental substrate $3,3^{\prime}$-dimethylbenzidine, the laccase may be five times more active in the rind than in the rest of the mushroom. The $\mathrm{pH}$ optimum with the natural substrate is not known; however, it is reasonable to assume it is also at an acidic $\mathrm{pH}$.

During the development of primordia and fruiting bodies of many fungi, liquid droplets are frequently exuded. It is our opinion that the extracellular liquid film must be of the correct $\mathrm{pH}$ for the function of extracellular enzymes critical to fruiting. This hypothesis was tested with flask cultures of $L$. edodes. With the oats medium, the formation of primordia and button-stage mushrooms occasionally occurred $18-22 \mathrm{~d}$ after inoculation. Two days before the pigmented primordia appeared above the white colony, tiny primordia buried in the mycelial mat produced clear exudation droplets above the mycelial mat, and these droplets gradually became pigmented. A pigmented primordium then often grew up through the droplet. The clear droplets fluoresced blue-white when excited by a long-wavelength ultraviolet source, but the droplets did not fluoresce after they had become pigmented by natural means or by the addition of the oxidant sodium periodate. These observations suggested that the droplets produced by the primordium may contain phenolic compounds. The $\mathrm{pH}$ of the growth medium beneath the mycelial mat was initially $6 \cdot 2 \pm 0 \cdot 15$. It dropped to $\mathrm{pH} 3.35 \pm 0.05$ by day $10-12$ and then remained at this $\mathrm{pH}$. At day 20 the $\mathrm{pH}$ of the exudation droplets produced was $3.6 \pm 0.1$ ( $\mathrm{pH}$ paper) and the extracellular $\mathrm{pH}$ of the cut primordium tissue was $5.3 \pm 0.2$ ( $\mathrm{pH}$ meter). With the xylose/cellulose/casein medium, the $\mathrm{pH}$ of the medium at the time of primordium development was $3 \cdot 2-4.0$ ( $\mathrm{pH}$ meter). The $\mathrm{pH}$ of the exudation droplets ( $\mathrm{pH}$ paper) with no visible primordia was $3.65 \pm 0.15$, and with 1-3 mm primordia under the droplet the $\mathrm{pH}$ was $3.95 \pm 0.4$. The droplets exuded by $8 \mathrm{~mm}$ and larger primordia had a $\mathrm{pH}$ of $4.25 \pm 0.1$. Tissue cut from $8 \mathrm{~mm}$ and larger primordia had an extracellular $\mathrm{pH}$ of $5.3 \pm 0.2$ ( $\mathrm{pH}$ meter). Wherever possible, measurement of individual exudation droplets by $\mathrm{pH}$ paper was verified by pooling the droplets and measuring with a $\mathrm{pH}$ meter. In some cases the measurements by $\mathrm{pH}$ paper may underestimate the $\mathrm{pH}$ of individual droplets by as much as $0.5 \mathrm{pH}$ units.

\section{The association of laccase with growth and development}

Using flask culture and xylose/cellulose/casein medium, three periods of apparent laccase production were detected. All, however, were observed to be associated with growth of aerial mycelium. The first period of laccase production was between days 6 and 10 after inoculation (Fig. 1c). At this time, aerial mycelium became visible. When the mycelial mat was gently removed from the flask during this period and the culture medium was assayed separately, most of the activity was in the medium (Fig. 1 b). It was apparent that the laccase had leached away from the mycelium into the medium. From day 12 onwards, an inhibitor of 3,3'-dimethylbenzidine oxidation accumulated in the medium along with a gradual increase of medium pigmentation. Based on assays with mixed homogenates, the inhibitor was found to 


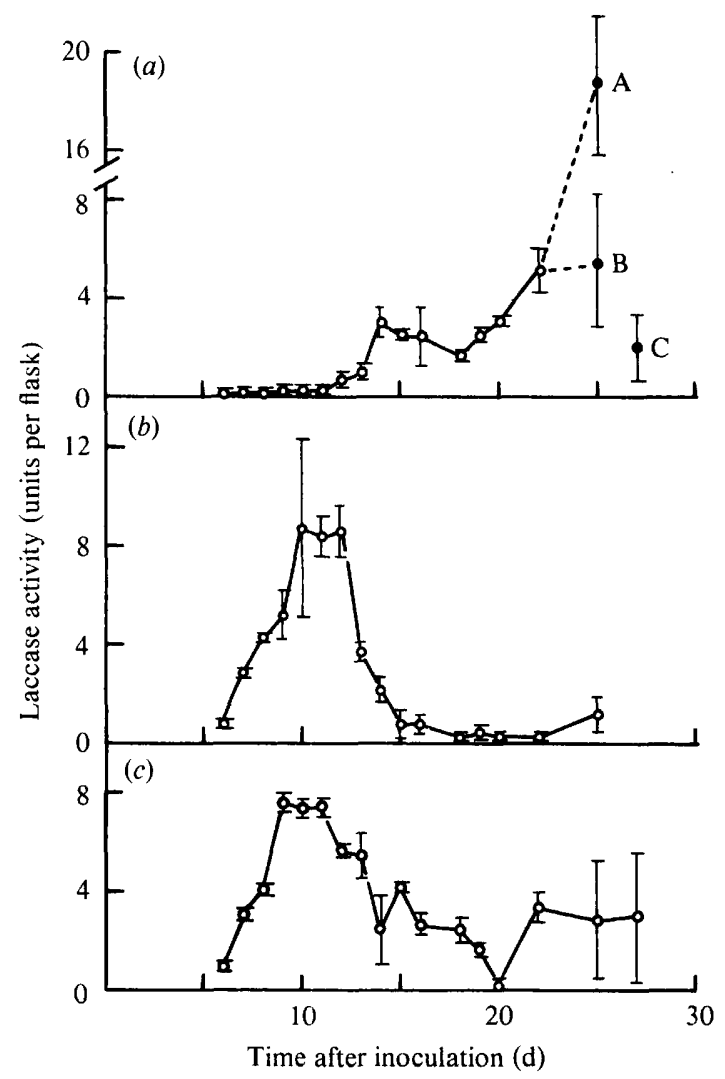

Fig. 1. Association of laccase activity with colony growth and the formation of primordia. The measurements were from duplicate cultures randomly selected, without replacement, from 200 cultures grown on xylose/cellulose/casein medium. Each point represents the mean (standard deviation bars shown) of the total units of laccase activity ( $\mu \mathrm{mol}$ substrate oxidized $\mathrm{min}^{-1}$ ) per flask for the fraction indicated, based on the steady-state oxidation rate of 3,3'-dimethylbenzidine in $21 \mathrm{~mm}$-sodium acetate buffer, $\mathrm{pH}$ 4.5. Homogenates were prepared from: $(a)$ the mycelium ( $\mathrm{O}, \mathrm{A}$, primordia only; $\bigcirc, \mathrm{B}$, mycelium minus primordia;, $\mathrm{C}$, mycelium from cultures not forming primordia); $(b)$ the culture medium from beneath the mycelium; $(c)$ the whole culture (mycelium plus culture medium).

cause a $90 \%$ inhibition of laccase activity in both the medium and the homogenates of whole culture flask contents (Fig. $1 b, c$ ). Therefore, to measure the activity in the mycelium, mycelial mats were removed from the culture flasks and placed medium-side down on a blotter for $5 \mathrm{~min}$. The tissue was then homogenized. Laccase was found to gradually accumulate in the mycelium from day 12 onwards (associated with increased density of the aerial mycelium) and sharply increased after day 25 (associated with the formation and growth of primordia). The sharp increase in laccase was exclusively in the buried and visible primordia and fruiting bodies (Fig. $1 a$ : A). Most of the laccase was released at all stages by homogenization with less than $30 \%$ breakage of individual cells (microscopic examination) and, therefore, was probably extracellular. Since the laccase from day 12 onwards was apparently extracellular but did not leach away from the mycelium, it was expected to be localized with the aerial mycelium.

\section{DISCUSSION}

Extracellular laccase(s) with a $\mathrm{pH}$ optimum near 4.0 was the major phenol oxidase(s) in fruiting bodies of $L$. edodes. In whole fresh mushroom homogenates the laccase was 
stimulated by the addition of $\mathrm{Cu}^{2+}$ and gave a single peak on gel chromatography with an apparent molecular weight of 100000 . Using flask-grown cultures, increased laccase activity was found to be correlated with rapid growth of aerial mycelium. The most marked increase in activity occurred with rapid growth of pigmented primordia. The maintenance of a liquid film with a pH near 4.0 may allow the function of laccase and other extracellular enzymes.

Since evaporation during mushroom growth has been reported to have important morphological consequences, extracellular liquid films may be important for normal development. Increased evaporation above a rather low level was reported to inhibit fruiting body growth in Flammulina (Collybia) velutipes (Plunkett, 1956). A dry stream of air was reported to induce formation of abnormal tremelloid outgrowths on the pileus of Coprinus ephemerus similar to those occasionally observed in nature (Keyworth, 1942).

Laccase and other phenol oxidases may participate in pigmentation reactions and in the strengthening of cell-to-cell adhesion. Mutants deficient in laccase in the ascomycete Podospora anserina exhibit reduced aerial mycelium and growth rate and aberrant morphology and coloration (Prillinger \& Esser, 1977). Yeast, an ascomycete, has been reported to contain a redox potential driven pump for the accumulation of $\mathrm{K}^{+}$coupled to $\mathrm{H}^{+}$ export (Conway, 1955). In the phycomycete Blastocladiella emersonii, the formation of NADPH by a NADP ${ }^{+}$-specific tyrosinase was metabolically coupled to the fixation of carbon dioxide needed for anaplerotic pathways. Thus $\mathrm{NADP}^{+}$replaced oxygen as the oxidant. This allowed the rapid formation of pigmented, thick-walled resistant spores under conditions in which the endogenous metabolism would otherwise be limiting (Cantino \& Lovett, 1964). It is interesting to speculate whether some form of metabolic coupling to phenol oxidases also occurs in higher fungi during periods when endogenous metabolism cannot keep up with cellular demands. Such conditions may occur during periods of rapid mobilization of food reserves and the biosynthesis of cell walls. For the rapidly growing pigmented primordium of $L$. edodes, cell wall biosynthesis must be a major metabolic undertaking.

Natural substrates for phenol oxidases are likely to be phenolic compounds which may be oxidized to reactive quinones. It is possible that, once generated, extracellular quinones may diffuse back into cells where they might damage the cell or alter (regulate) cellular metabolism. Such a possibility has been suggested with oxidation products of indoleacetic acid in plants (Stahmann \& Demorest, 1973). Fungi often excrete phenolic compounds into their growth medium (Packter, 1970). In the case of L. edodes, the phenolic compounds might be oxidized by the extracellular laccase. It is not known if the metabolism of $L$. edodes would be affected by natural quinones or changes of redox potential of the growth medium due to the presence of quinones. However, vegetative growth of the basidiomycete Armillariella mellea was reported to be markedly sensitive to redox potential (Jennison et al., 1955). On natural substrates, the presence of an extracellular laccase may have other roles in growth. Delignification and regulation of metabolism has been reported to be correlated with extracellular laccases in Phanerochaete chrysosporium (Sporotrichum pulverulentum) (Ander \& Eriksson, 1976). In the vegetative mycelium of the ascomycete Leptosphaerulina briosiana, cytochemical staining with a laccase substrate showed laccase to be localized in the outer cell wall (Simon et al., 1979). In studies of the formation of fruiting bodies of gel-containing discomycetes, a gel precursor material was found to be secreted directly by specialized secretory cells. After secretion the mucilage underwent a viscosity change, of unknown mechanism, and then it clung to the celis and between adjacent cells (Moore, 1965). Recently, a similar mucilage was reported apparently binding adjacent hyphae together in primordia of the basidiomycetes Schizophyllum commune and Coprinus cinereus (Van der Valk \& Marchant, 1978). It is interesting to speculate that phenol oxidase and the mucilage are involved in an oxidative polymerization process. Such a process, termed 'oxidative gelation', has recently been characterized for wheat flour pentosans. It involves a natural phenolic compound covalently conjugated to a soluble pentosan containing $8 \%$ protein. In 
the presence of an oxidizing agent, the pentosan polymerizes into a gel (Neukom \& Markwalder, 1978). Relatively low concentrations of many classes of phenolic compounds have been found to participate in in vitro cross-linking reactions with proteins (Stahmann et al., 1977; Leatham et al., 1980).

During studies on the maturation of fruiting bodies of the basidiomycete Polyporus hispidus, it was found that hispidin (a natural phenolic compound) became less susceptible to ethanol extraction as the fruiting body pigmented and became more fibrous and woody (Bu'lock, 1967). In further studies on the maturation of fruiting bodies, with the basidiomycete Daldinia concentrica, it was found that a natural phenolic substrate was oxidized, depositing a black pigment on to the cell walls which gave them great structural integrity, making them collapse-resistant to repeated ethanol extractions. These observations led to the hypothesis that oxidative cross-linking occurred within the cellular matrix of the fruiting bodies (Bu'lock, 1967). We support the hypothesis that during morphogenesis in higher fungi the phenol oxidase-catalysed formation of extracellular pigments is coupled to oxidative polymerization of cell wall components strengthening cell-to-cell adhesion.

The authors wish to thank Dr T. J. Leonard for helpful suggestions during this study, Dr J. C. Garver and Art Olson for use and instruction in the use of the large-scale fermentation equipment and autoclave, Dr R. H. Burris for use of the Gilson spectrophotometer and Dr Lung-Chi Wu for help in the development of the media and for guidance during the early stages of this study. The study was supported in part by the Graduate School, University of Wisconsin-Madison, from funds supplied by the Wisconsin Alumni Research Foundation.

\section{REFERENCES}

ANDER, P. \& ERIKsson, K.-E. (1976). The importance of phenol oxidase activity in lignin degradation by the white-rot fungus Sporotrichum pulverulentum. Archives of Microbiology 109, 1-8.

Bull, A. T. \& CARTER, B. L. A. (1973). The isolation of tyrosinase from Aspergillus nidulans, its kinetic and molecular properties and some consideration of its activity in vivo. Journal of General Microbiology 75, 61-73.

Bu'LOCK, J. D. (1967). Fungal metabolites with structural function. In Essays in Biosynthesis and Microbial Development, E. R. Squibb Lectures on Chemistry of Microbial Products, pp. 1-18. New York: Wiley.

Cantino, E. C. \& Lovetr, J. S. (1964). Nonfilamentous aquatic fungi: model systems for biochemical studies of morphological differentiation. Advances in Morphogenesis 3, 33-93.

ConwaY, E. J. (1955). Evidence for a redox pump in the active transport of cations. International Review of Cytology 4, 377-396.

DANIEL, J. W. (1963). Metabolism of the phenolic precursor of a myxomycete spore pigment. Journal of Cell Biology 19, 18A-19A.

DAvis, B. J. (1964). Disc electrophoresis II. Method and applications to human serum proteins. Annals of the New York Academy of Sciences 121, 404-427.

EsSER, K. (1968). Phenol oxidases and morphogenesis in Podospora anserina. Genetics 60, 281-288.

Fujimoto, K., MiYashiro, M. \& Kaneda, T. (1972). Enzymatic browning reaction of the shiitake mushroom and its prevention. Mushroom Science 8, 861-866.

Hackman, R. H. (1959). Biochemistry of the insect cuticle. Proceedings of the 4th International Congress of Biochemistry, Vienna, 1958 14, 48-62.
Harkin, J. M., Larsen, M. J. \& Obst, J. R. (1974). Use of syringaldazine for detection of laccase in sporophores of wood rotting fungi. Mycologia 66, 469-476.

HiguchI, T. (1959). Studies on the biosynthesis of lignin. Proceedings of the 4th International Congress of Biochemistry, Vienna, 1958 2, 161-188.

Jennison, M. W., Newcomb, M. D. \& Henderson, R. (1955). Physiology of the wood-rotting basidiomycetes. I. Growth and nutrition in submerged culture in synthetic media. Mycologia 47, 275-304.

KEYWORTH, W. G. (1942). The occurrence in artificial culture of tremelloid outgrowths on the pilei of Coprinus ephemerus. Transactions of the British Mycological Society 25, 307-310.

Leatham, G. F., King, V. \& StahmanN, M. A. (1980). Polymerization of proteins in vitro by quinones or free radicals generated by plant and fungal oxidase systems. Phytopathology 70, 11341140.

Leonard, T. J. \& Phillips, L. E. (1973). Study of phenoloxidase activity during the reproductive cycle in Schizophyllum commune. Journal of Bacteriology 114, 7-10.

Mason, H. S. (1955). Comparative biochemistry of the phenolase complex. Advances in Enzymology 16, 105-184.

Mason, H. S. (1957). Mechanism of oxygen metabolism. Advances in Enzymology 19, 79-233.

MOORE, E. J. (1965). Fungal gel tissue ontogenesis. American Journal of Botany 52, 389-395.

Neukom, H. \& Markwalder, H. U. (1978). Oxidative gelation of wheat flour pentosans: a new way of cross-linking polymers. Cereal Foods World 23, 374-376. 
Northcote, D. H. (1972). Chemistry of the plant cell wall. Annual Review of Plant Physiology 23, 113-132.

PACKTER, N. M. (1970). Studies on the biosynthesis of phenols in fungi. Production of 4-methoxytoluquinol, epoxysuccinic acid and a diacetylenic alcohol by surface cultures of Lentinus degener. Biochemical Journal 114, 369-377.

Plunkett, B. E. (1956). The influence of the factors of the aeration complex and light upon fruit-body form in pure cultures of an agaric and a polypore. Annals of Botany 20, 563-586.

Prillinger, H. \& Esser, K. (1977). The phenoloxidases of the ascomycete Podospora anserina. XIII. Action and interaction of genes controlling the formation of laccase. Molecular and General Genetics 156, 333-346.

Schubert, W. J. (1965). Lignin Biochemistry, p. 82. New York: Academic Press.

Simon, L. T., Bishop, D. S. \& Hooper, G. R. (1979). Ultrastructure and cytochemical localization of laccase in two strains of Leptosphaerulina briosiana (Pollaci) Graham and Luttrell. Journal of Bacteriology 137, 537-544.

Stahmann, M. A. \& Demorest, D. M. (1973). Changes in enzymes of host and pathogen with special reference to peroxidase interaction. In Fungal Pathogenicity and the Plant's Response, pp. 405-422. Edited by R. J. W. Byrde \& C. V. Cutting. London: Academic Press:

Stahmann, M. A., Spencer, A. K. \& Honold, G. R. (1977). Cross-linking of proteins in vitro by peroxidase. Biopolymers 16, 1307-1318.

VAN DER VALK, P. \& Marchant, R. (1978). Hyphal ultrastructure in fruit-body primordia of the basidiomycetes Schizophyllum commune and Coprinus cinereus. Protoplasma 95, 57-72.

Wong, A.-L. \& Willetts, H. J. (1974). Polyacrylamide-gel electrophoresis of enzymes during morphogenesis of sclerotia of Sclerotinia sclerotiorum. Journal of General Microbiology 81, 101-109.

Wood, D. A. (1980). Production, purification and properties of extracellular laccase of Agaricus bisporus. Journal of General Microbiology 117, 327-338.

Wood, D. A. \& Goodenough, P. W. (1977). Fruiting of Agaricus bisporus. Changes in extracellular enzyme activities during growth and fruiting. Archives of Microbiology 114, 161-165. 